\title{
Penerapan Metode Eksperimen Semu Pada Sistem Informasi Persediaan Dan Penjualan Obat Di Apotek Berbasis Web-Base
}

\author{
Sutono $^{1}$, Aditya Prasetya Pamungkas ${ }^{2}$ \\ Program Studi Teknik Informatika \\ Fakultas Teknik Universitas Suryakancana \\ sutono@unsur.ac.id ${ }^{1}$, adityaprasetya274@gmail.com²
}

\begin{abstract}
The development of Information Technology makes various activities in human life undergo evolution. This dynamic condition gave rise to information system breakthroughs in response to the old system. Systems that are carried out conventionally began to be abandoned and switched to computerized systems. Apotek Sahabat is a company engaged in the trading business by providing all kinds of medicines for people who are less healthy and need medicine. However, the sales service system available at Apotek Sahabat is still using conventional methods, pharmacy officers write notes for the purchase of medicines ordered by customers. Data collection and counting of goods in the warehouse are still using the old method, warehouse officers must check one by one and write them into a book containing the stock and name of the goods. This obstacle often makes pharmacy officers feel difficult because they have to serve several customers when the pharmacy is busy being visited. The method used is a quasi-experimental method. Quasi-experimental is a research method that is used to generate data and test hypotheses that are controlled appropriately. To determine the effects, it must be designed and then tested. And in making this software, a system development method is used based on the waterfall paradigm with UML (Unified Modeling Language) with the tools used to design namely Usecase Diagrams, Swimlane Diagrams, Class Diagrams, and Sequence Diagrams while in making this application using the programming language PHP, HTML. and MYSQL as a database management system. Therefore, the Sales Inventory information system is better than a manual system, which produces three actors involved in it, which makes management within the company run more effectively and efficiently and the sales system is more conducive.
\end{abstract}

Keywords: Information Systems, Quasi-Experimental Methods, Sales Inventory, Unified Modeling Language, PHP, $H T M L W E B, M Y S Q L$

\begin{abstract}
Abstrak
Perkembangan Teknologi Informasi membuat berbagai aktivitas dalam kehidupan manusia mengalami evolusi. Kondisi dinamis ini memunculkan terobosan-terobosan sistem informasi sebagai jawaban atas sistem lama. Sistem yang dilakukan secara konvensional mulai ditinggalkan dan beralih ke sistem komputerisasi. Apotek Sahabat merupakan sebuah perusahaan yang bergerak di bidang usaha dagang dengan menyediakan segala macam obat-obatan untuk orang orang yang kurang sehat dan membutuhkan obat. Akan tetapi sistem pelayanan penjualan yang tersedia di Apotek Sahabat ini masih menggunakan cara konvensional, petugas apotek menuliskan nota pembelian obat-obatan yang di pesan oleh pelanggan. Pendataan dan penghitungan barang yang ada di gudang pun masih menggunakan cara lama, petugas gudang harus cek satu persatu dan menuliskannya kedalam buku yang berisi stok dan nama barang. Kendala ini sering membuat petugas apotek merasa keropotan karena harus melayani beberapa pelanggan ketika Apotek sedang ramai dikunjungi. Metode yang digunakan adalah metode ekperimen semu. Eksperimen semu merupakan metode penelitian yang digunakan untuk menghasilkan suatu data dan menguji hipotesis yang dikontrol dengan tepat, untuk mengetahui akibat yang ditimbulkan, maka harus dirancang dan kemudian di uji coba. Dan dalam pembuatan perangkat lunak ini digunakan metoda pengembangan sistem berdasarkan paradigma waterfall dengan UML (Unified Modeling Language) dengan alat yang digunakan untuk merancang yaitu Usecase Diagram, Swimlane Diagram, Class Diagram, dan Sequence Diagram sedangkan dalam pembuatan aplikasi ini menggunakan Bahasa pemrograman PHP, HTML dan MySQL sebagai database management system. Maka dari itu dengan sistem informasi Inventory Penjualan ini lebih baik dari sistem yang manual, yang menghasilkan tiga aktor yang terlibat didalamnya, yang membuat manajemen didalam perusahaan berjalan lebih efektif dan efisien serta sistem penjualanlebih kondusif.
\end{abstract}

Kata kunci : Sistem Informasi, Metode Experimental Semu, Inventory Penjualan, Unified Modeling Language, PHP, HTML WEB, $M Y S Q L$ 


\section{Latar Belakang Masalah}

Perkembangan Teknologi Informasi membuat berbagai aktivitas dalam kehidupan manusia mengalami evolusi. Kondisi dinamis ini memunculkan terobosanterobosan sistem informasi sebagai jawaban atas sistem lama. Sistem yang dilakukan secara konvensional mulai ditinggalkan dan beralih ke sistem komputerisasi, yang dirasa lebih cepat dan akurat dalam penyampaian informasi serta kecepatan pengolahan data seperti mengelola berbagai laporan transaksi, mengelola data perusahaan maupun data lainnya yang dibutuhkan oleh perusahaan. Penyampaian informasi memiliki peran yang sangat penting bagi setiap perusahaan, terutama pada perusahaan-perusahaan yang memiliki tingkat rutinitas yang tinggi dan memiliki data yang harus diolah

Persediaan (Inventory) merupakan salah satu faktor penting dalam sebuah perusahaan untuk mendukung keseimbangan proses produksi dan mencapai tujuan perusahaan. Menurut (Rangkuti, 2004) Persediaan (inventory) merupakan suatu aktivas yang meliputi barang-barang milik perusahaan dengan maksud untuk dijual dalam suatu periode usaha tertentu, atau persediaan barang-barang yang masih dalam pengerjaan atau proses produksi, ataupun persediaan bahan baku yang menunggu penggunaannya dalam suatu proses produksi.

Penjualan adalah sebuah usaha atau langkah konkrit yang dilakukan untuk memindahkan suatu produk, baik itu berupa barang atau jasa, dari produsen kepada konsumen sebagai sasarannya. Tujuan utama penjualan yaitu mendatangkan keuntungan atau laba dari produk atau barang yang dihasilkan produsennya dengan pengelolaan yang baik. Dalam pelaksanaannya, penjualan sendiri tak akan dapat dilakukan tanpa adanya pelaku yang bekerja didalamnya seperti agen, pedangang, dan tenaga pemasaran.

Apotek Sahabat merupakan sebuah perusahaan yang bergerak di bidang usaha dagang dengan menyediakan segala macam obat-obatan untuk orang orang yang kurang sehat dan membutuhkan obat. Akan tetapi sistem pelayanan penjualan yang tersedia di Apotek Sahabat ini masih menggunakan cara konvensional, petugas apotek menuliskan nota pembelian obat-obatan yang di pesan oleh pelanggan. Pendataan dan penghitungan barang yang ada di gudang pun masih menggunakan cara lama, petugas gudang harus cek satu persatu dan menuliskannya kedalam buku yang berisi stok dan nama barang. Kendala ini sering membuat petugas apotek merasa keropotan karena harus melayani beberapa pelanggan ketika Apotek sedang ramai dikunjungi. Metode pencatatan nota tersebut dinilai masih kurang efektif dan efisien dalam beberapa aspek seperti keakuratan, keamanan data dan kecepatan akses. Selain itu, informasi yang dihasilkan pun dirasa kurang akurat.

Berdasarkan paparan diatas diperlukan sebuah aplikasi yang memanfaatkan komputer untuk menangani dan mengolah data-data dengan menggunakan aplikasi. Dalam penelitian ini juga peneliti menggunakan metode eskperimen semu yang digunakan untuk menghasilkan suatu data dan menguji hipotesis yang dikontrol dengan tepat untuk mengetahui akibat yang ditimbulkan. Diharapkan dengan adanya aplikasi tersebut, dapat memudahkan dan dapat menghindari kesalahan dalam pengolahan data.

Maksud penelitian ini adalah membuat sebuah Sistem Informasi Inventory Dan Penjualan Obat Apotek Sahabat Menggunakan Metode Eksperimen Semu Berbasis Web. Adapun tujuan penelitian ini adalah sebagai berikut :
a. Mempermudah pendataan barang
b. Pengelolaan barang cepat dan efisien.
c. Mempermudah transaksi penjualan
d. Mempermudah pencarian barang.
e. Update stok barang gudang secara Real-time.
f. Pembuatan laporan penjualan.

\section{Landasan Teori}

\subsection{Sistem Informasi}

Sistem Informasi merupakan suatu sistem yang menyediakan informasi untuk manajemen dalam mengambil keputusan dan juga untuk menjalankan operasional perusahaan, di mana sistem tersebut merupakan kombinasi dari orang-orang, teknologi informasi dan prosedur-prosedur yang tergorganisasi. Biasanya suatu perusahan atau badan usaha menyediakan semacam informasi yang berguna bagi manajemen. Sistem informasi memiliki komponen yang berupa subsistem yang merupakan elemen-elemen yang lebih kecil yang membentuk sistem informasi tersebut misalnya bagian input, proses, output (Jogiyanto H. , 2005).

\subsection{Pengertian Inventory (Persediaan)}

Persediaan merupakan suatu aktivitas yang meliputi barang-barang milik perusahaan dengan maksud untuk dijual dalam suatu periode usaha tertentu, atau persediaan barang-barang yang masih dalam pengerjaan atau proses produksi, ataupun persediaan bahan baku yang menunggu penggunaannya dalam suatu proses produksi. (Rangkuti, 2004). Persediaan (Inventory) adalah bagian yang disediakan dalam proses yang terdapat dalam suatu perusahaan untuk di produksi, serta barang jadi yang di sediakan untuk memenuhi permintaan dari konsumen setiap waktu yang disimpan dan di rawat menurut aturan tertentu dalam keadaan siap pakai dan tersimpan dalam database. (Fahrisa, Sentosa Pohan, \& Marnis Nasution, 2018)

\subsection{Eksperimen Semu}

Kuasi Eksperimen adalah eksperimen yang memiliki perlakuan (treatments), pengukuran pengukuran dampak (outcome measures), dan unit-unit eksperiment (experimental units) namun tidak menggunakan penempatan secara acak. Pada penelitian lapangan biasanya menggunakan rancangan eksperiment semu (kuasi eksperimen). Desain tidak mempunyai pembatasan yang ketat terhadap randomisasi, dan pada saat yang sama dapat mengontrol ancaman-ancaman validitas. Di sebut eksperimen semu karena eksperimen ini belum atau tidak memiliki cir-ciri rancangan eksperimen yang sebenarnya, karena variabel-variabel yang seharusnya dikontrol atau di manipulasi.Oleh sebab itu validitas penelitian menjadi kurang cukup untuk disebut sebagai eksperimen yang sebenarnya. "eksperimen hampir mirip dengan eksperimen yang 
sebenarnya. Perbedaannya terletak pada penggunaan subyek yaitu pada kuasi eksperimen tidak dilakukan penugasan random, melainkan dengan menggunakan kelompok yang telah ada (intact group". (Ali, 1992). Menurut (Sukmadinata, 2004) Eksperimen ini disebut kuasi, karena bukan merupakan eksperimen murni tetapi seperti murni, seolah-olah murni. Eksperimen ini biasa juga disebut eksperimen semu. Karena berbagai hal, terutama berkenaan dengan pengontrolan variabel, kemungkinan sukar sekali dapat digunakan eksperimen murni. Eksperimen kuasi bisa digunakan minimal kalau dapat mengontrol satu variabel saja meskipun dalam bentuk matching, atau memasangkan/menjodohkan karakteristik. Berikut merupakan langkah-langkah dalam eksperimen semu

a. Melakukan tinjauan literature, terutama yang berhubungan dengan masalah yang akan diteliti.

b. Mengidentifikasi dan membatasi masalah penelitian.

c. Merumuskan hipotesis-hipotesis penelitian

d. Menyusun rencana eksperimen,

e. Melakukan pengumpulan data (Kuisioner).

f. Melakukan eksperimen

g. Mengolah dan menganalisis data.

h. Menarik kesimpulan.

\section{Analisis dan Perancangan}

\subsection{Usecase Diagram}

Use case diagram menggambarkan fungsionalitas yang diharapkan dari sebuah sistem. Yang ditekankan adalah "apa" yang diperbuat sistem, dan bukan "bagaimana". Sebuah use case mempresentasikan sebuah interaksi antara aktor dengan sistem. Terdapat pada gambar 1

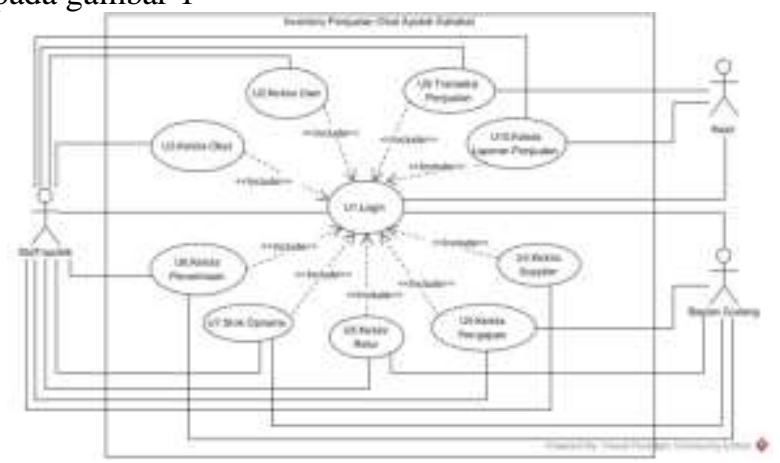

Gambar 1 Use Case Diagram

Use Case Diagram pada gambar 1 terdapat 10 use case dan 3 aktor. Staff Apotek yaitu orang yang mengelola semua fungsi. Kasir yaitu orang yang mengelola transaksi penjualan dan laporan penjualan, Bagian Gudang yaitu orang yg mengelola fungsi penerimaan, pengajuan, retur dan stock opname. Setiap aktor harus melakukan login untuk bisa menggunakan fungsi dan setiap aktor memiliki hak aksesnya masing masing

3.2Class Diagram

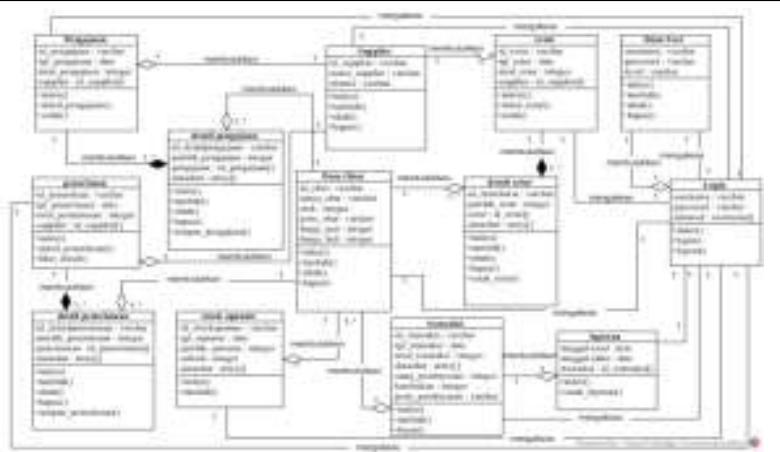

Gambar 2 Class Diagram

Pada Gambar 2 class diagram inventory dan penjualan ini terdapat 13 class ayng terdiri dari class login, data obat, data user, data supplier, pengajuan, detail pengajuan, penerimaan, detail penerimaan, retur, detail retur, stock opname, transaksi penjualan dan laporan transaksi

3.3Entity Relationship Diagram

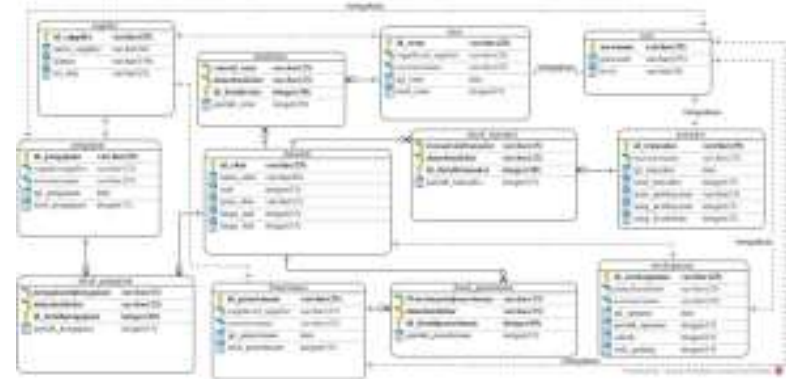

Gambar 3 Entity Relationship Diagram

Pada entity relationship diagram Inventory Dan Penjualan ini terdapat 12 tabel yaitu data obat, data user, data supplier, pengajuan, detail pengajuan, penerimaan, detail penerimaan, retur,detail retur, stock opname, transaksi dan detail transaksi

\section{Implementasi Sistem}

Implementasi sistem adalah suatu prosedur yang dilakukan untuk menyelesaikan program aplikasi, penulisan kode program merupakan kegiatan yang terbesar dalam tahap ini. Sementara itu Pengujian Sistem merupakan suatu cara mengetahui dan meminimalisasi kesalahan yang mungkin timbul pada aplikasi yang dibangun. Teknologi yang digunakan pada perancangan dan implementasi sistem ini terdiri dari tiga bagian yaitu

\subsection{Impementasi Perangkat Keras}

Spesifikasi perangkat keras yang digunakan untuk membangun aplikasi inventory penjualan berbasis WEB di Apotek Sahabat sebagai berikut :
a. Processor Intel(R) Celeron(R) CPU B820 @ 1.70Ghz (2 CPUs)
b. VGA Intel(R) HD Graphics 3000 dan NVIDIA GeForce 610M
c. Harddisk $500 \mathrm{~GB}$
d. 4 GB RAM
e. Mouse dan Keyboard
f. Printer

\subsection{Impementasi Perangkat Lunak}

Selain perangkat keras, dalam implementasi aplikasi inventory penjualan berbasis WEB di Apotek 
Sahabat dibutuhkan juga perangkat lunak. Berikut ini merupakan spesifikasi perangkat lunak yang digunakan diantaranya :
a. Microsoft Windows 10
b. Visual Paradigm 13.0
c. Balsmiq Mockups 3
d. Sublime
e. Xampp yang terdiri dari perangkat lunak Apache, Mysql, PHP, dan Perl
f. Web browser google chrome

\section{Implementasi Antarmuka}

1. Halaman Login

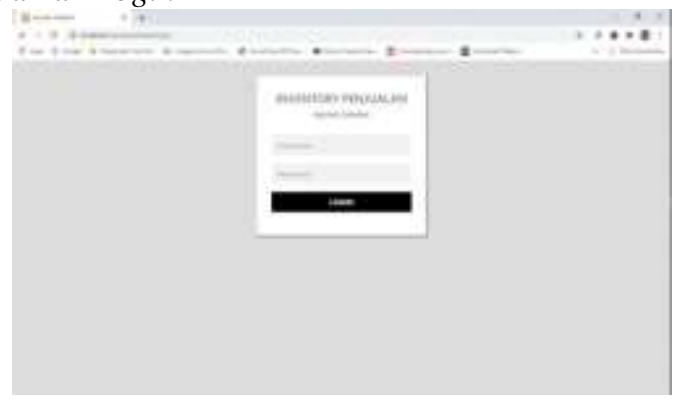

2. Halaman Utama

Gambar 4 Halaman Login

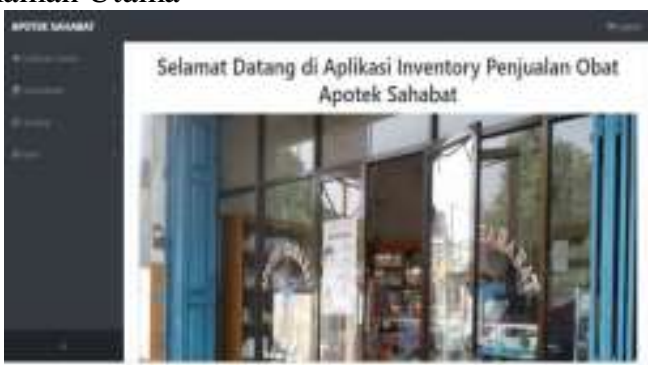

Gambar 5 Halaman Utama

3. Halaman Data Obat

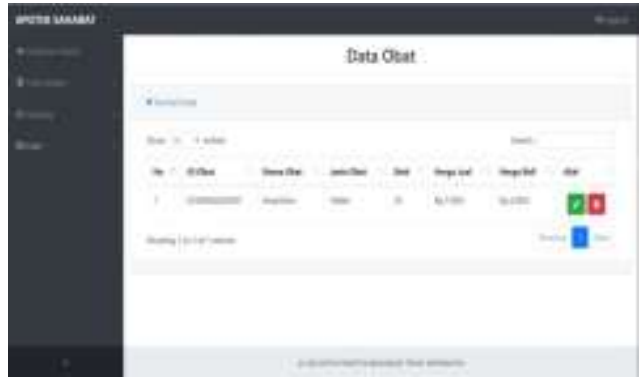

Gambar 6 Halaman Data Obat

4. Halaman Data Supplier

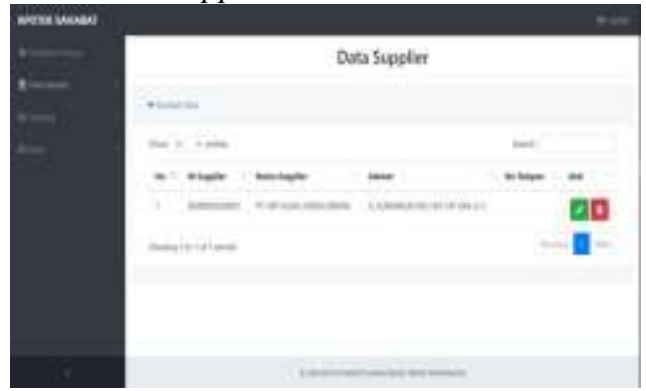

Gambar 7 Halaman Data Supplier

5. Halaman Data User

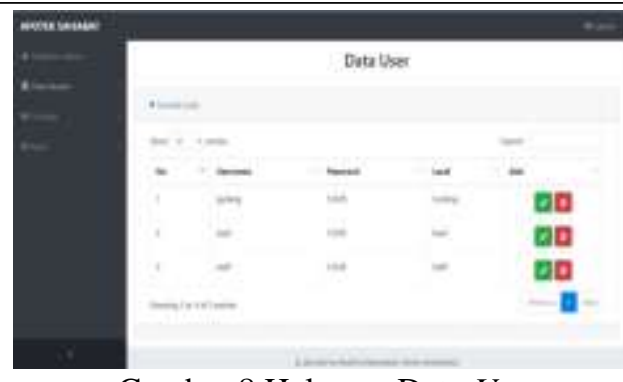

Gambar 8 Halaman Data User

6. Halaman Pengajuan

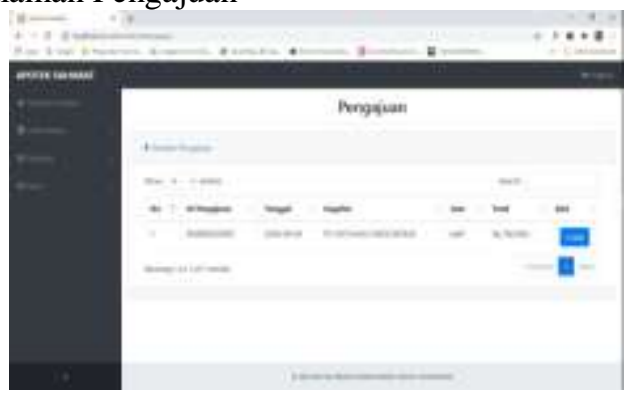

Gambar 9 Halaman Pengajuan

7. Halaman Detail Pengajuan

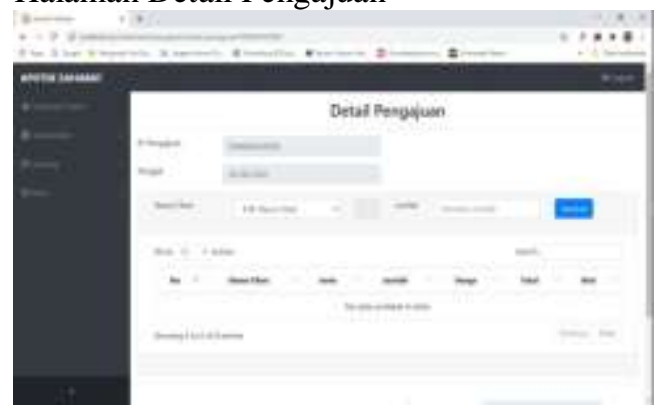

Gambar 10 Halaman Detail Pengajuan

8. Halaman Penerimaan

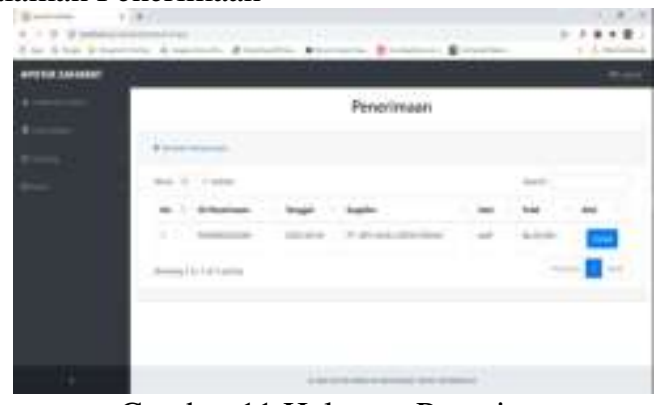

Gambar 11 Halaman Penerimaan

9. Halaman Detail Penerimaan

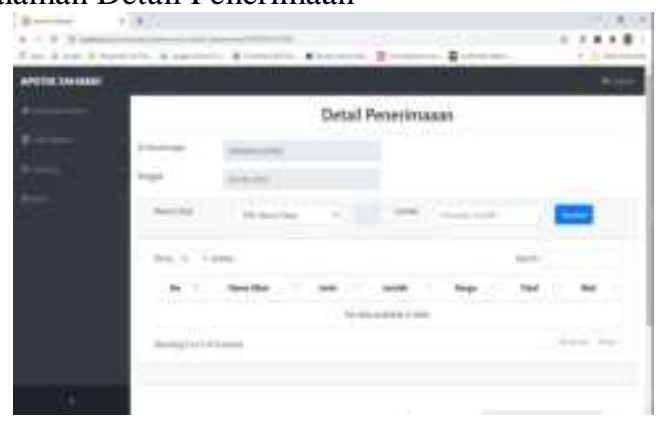

Gambar 12 Halaman Detail Penerimaan 


\section{Halaman Retur}

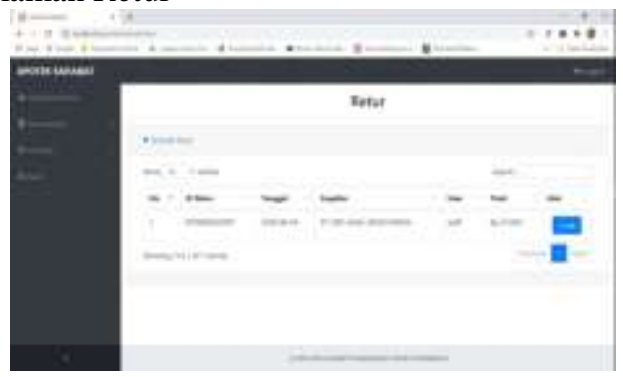

Gambar 13 Halaman Retur

11. Halaman Detail Retur

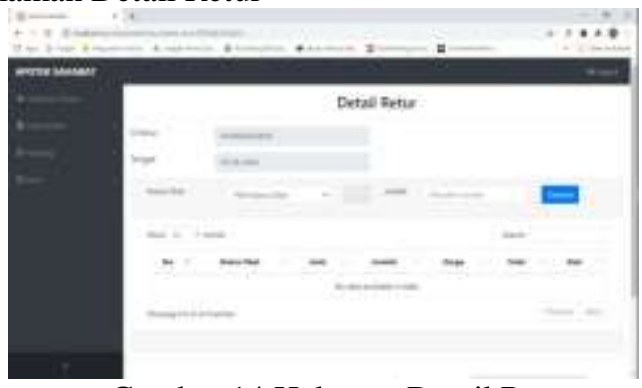

Gambar 14 Halaman Detail Retur

12. Halaman Stock Opname

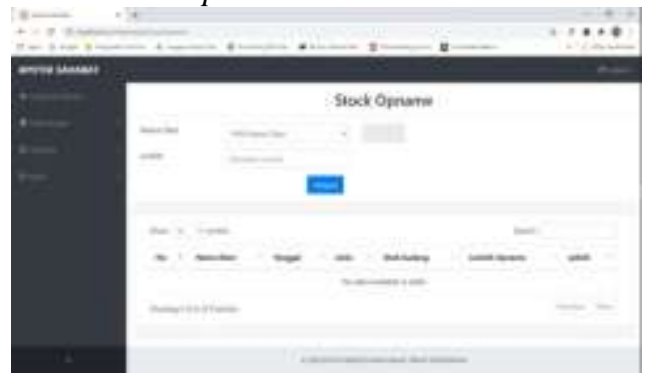

Gambar 15 Halaman Stock Opname

13. Halaman Transaksi Penjualan

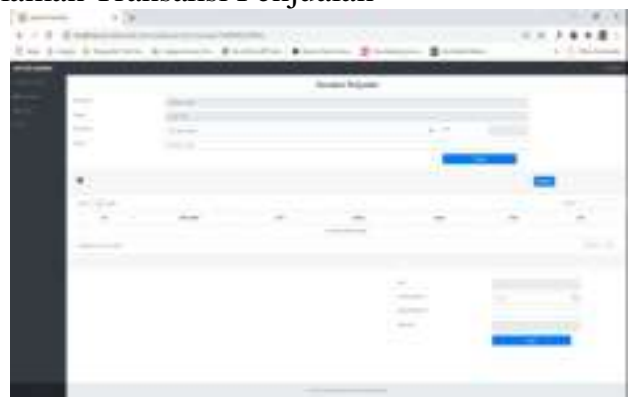

Gambar 16 Halaman Transaksi Penjualan

14. Halaman Laporan Transaksi

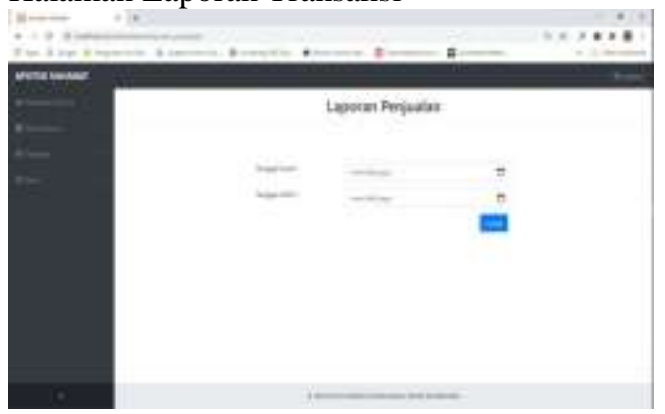

Gambar 17 Halaman Laporan Transaksi

\section{Eksperimen}

Dalam eksperimen ini dilakukan percobaan dengan memberikan kuisioner sebelum menggunakan aplikasi dan kuisioner sesudah menggunakan aplikasi kepada seluruh karyawan apotek sahabat yang berjumlah 7 orang untuk diolah datanya yang kemudian ditarik kesimpulannya.

\section{Mengolah dan Menganalisis Data}

Dalam mengolah dan menganalisis datanya menggunakan modifikasi skala likert yang perhitungannya sebagai berikut :

Rumus : $\mathrm{P}=\mathrm{S} /$ Skor ideal $\mathrm{x} 100$

Dimana :

$\mathrm{P}=$ Nilai persentase yang dicari

$\mathrm{S}=$ Jumlah Frekuensi jawaban dikalikan

dengan nilai pernyataan

Skor Ideal = Nilai pernyataan tertinggi

dikalikan dengan jumlah sampel.

Karena responded hanya terdiri dari 7 orang, maka Skor Ideal dapat dihitung dengan jumlah pernyataan tertinggi yaitu 5 dikali jumlah sampel yaitu 7 , jadi 5 x 7 $=35$.

Keterangan :

SS : Sangan Setuju $=5$ poin

$S:$ Setuju $=4$ poin

CS : Cukup Setuju $=3$ poin

KS: Kurang Setuju $=2$ poin

STS: Sangat Tidak Setuju $=1$ poin

a. Hasil Perhitungan Kuisioner Sebelum Memakai Aplikasi

\begin{tabular}{|c|c|c|c|c|c|}
\hline Pernyatzan & Kat & Fain & Frekaumai & Total(Peins F) & Havil (P) \\
\hline \multirow{2}{*}{1} & 55 & 3 & 1 & \multirow{2}{*}{$5-24=29$} & $20 / 33 \times 100=$ \\
\hline & s & 4 & 6 & & 8246 \\
\hline \multirow{2}{*}{2} & 55 & 5 & $\frac{2}{2}$ & \multirow{2}{*}{$10+20-30$} & $70 / 35 \approx 100=$ \\
\hline & s & 4 & 5 & & 8556 \\
\hline \multirow{2}{*}{3} & 5. & 4 & 6 & \multirow{2}{*}{$24-3=22$} & $27 / 35 \times 100=$ \\
\hline & cs & 3 & 1 & & $77 \%$ \\
\hline \multirow{2}{*}{4} & 5 & 4 & $T$ & \multirow{2}{*}{$2 \pi$} & $28 / 55 \times 100=$ \\
\hline & & & & & 8046 \\
\hline \multirow{2}{*}{2} & 55 & 3 & 4 & \multirow{2}{*}{$20+12-32$} & $32 / 35 \times 100=$ \\
\hline & 5 & 4 & 3 & & $91 \%$ \\
\hline \multirow{2}{*}{6} & ss & 5 & 3 & \multirow{2}{*}{$15+16=31$} & $31 / 33 \times 100=$ \\
\hline & 5 & 4 & 4 & & 8896 \\
\hline \multirow{2}{*}{7} & s5 & 3 & 4 & \multirow{2}{*}{$20+12-32$} & $32 / 35=100=$ \\
\hline & s & 4 & 3 & & 9140 \\
\hline \multirow{3}{*}{8} & 55 & 5 & 1 & \multirow{3}{*}{$5+16+6-27$} & \\
\hline & s & 4 & 4 & & t20 \\
\hline & cs & 3 & 2 & & \\
\hline \multirow{2}{*}{9} & ss & 1 & 4 & \multirow{2}{*}{$20-12=32$} & $32 / 35 \times 100=$ \\
\hline & 5 & 4 & 3 & & $91 \% 6$ \\
\hline \multirow{2}{*}{10} & $\mathrm{kS}$ & 2 & 4 & \multirow{2}{*}{$8+3-12$} & $12 / 35=1000=$ \\
\hline & 5TS & 1 & 3 & & 3446 \\
\hline
\end{tabular}

Gambar 18 Hasil Perhitungan Kuisioner Sebelum Memakai Aplikasi 
b. Hasil Perhitungan Kuisioner Sesudah Memakai Aplikasi

\begin{tabular}{|c|c|c|c|c|c|}
\hline Perpigas & Eot & Foir & Fecheser & 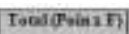 & स्समान (क) \\
\hline \multirow{2}{*}{1} & 35 & 5 & 7 & \multirow{2}{*}{$30+2=34$} & $14 / 31=100=$ \\
\hline & 3 & 4 & 1 & & $97 \%$ \\
\hline \multirow{2}{*}{2} & 35 & 4 & $\tau$ & \multirow{2}{*}{ 39 } & $35 \times 3=100-$ \\
\hline & & & & & toses: \\
\hline \multirow[b]{2}{*}{$y$} & 35 & 5 & 2 & \multirow{2}{*}{$10-20=30$} & $30<35=100$ \\
\hline & 8 & 4 & s & & 253, \\
\hline \multirow{2}{*}{4} & 38 & 8 & 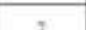 & \multirow{2}{*}{ 3) } & $39 / 33 \times 100=$ \\
\hline & 38 & 7 & 3 & & $100 \%$ \\
\hline \multirow{2}{*}{5} & 35 & 5 & 6 & \multirow{2}{*}{$30+2=34$} & $3+33=100=$ \\
\hline & 3 & 4 & 1 & & 975 \\
\hline \multirow{2}{*}{ if } & 98 & 9 & 6 & \multirow{2}{*}{$2+a-4$} & $3435 \times 100=$ \\
\hline & s & 4 & 1 & & 974 \\
\hline \multirow{2}{*}{7} & 35 & 5 & 6 & \multirow{2}{*}{$30+4=34$} & $34 / 33=100=$ \\
\hline & 8 & 4 & 1 & & 976 \\
\hline \multirow{2}{*}{8} & 55 & 5 & 2 & \multirow{2}{*}{$10-20=30$} & $30 \times 35=100=$ \\
\hline & 3 & 4 & , & & $E \%$ \\
\hline \multirow{2}{*}{9} & \multirow{2}{*}{ ss. } & \multirow{2}{*}{9} & \multirow[b]{2}{*}{ 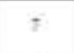 } & \multirow{2}{*}{3} & $35 / 35=1020$ \\
\hline & & & & & tosts \\
\hline \multirow{2}{*}{10} & 35 & 5 & 5 & \multirow{2}{*}{$10=30=30$} & $30 / 35=105=$ \\
\hline & 9 & 4 & 2 & & 15\%8 \\
\hline
\end{tabular}

Gambar 19 Hasil Perhitungan Kuisioner Sesudah Memakai Aplikasi

Kriteria interpretasi skor berdasarkan interval

\begin{tabular}{|c|c|}
\hline Angka Presentase & Hasil \\
\hline $1 \%-20 \%$ & Sangat Tidak Setuju \\
\hline $21 \%-40 \%$ & Kurang Setuju \\
\hline $41 \%-60 \%$ & Cukup Setuju \\
\hline $61 \%-80 \%$ & Setuju \\
\hline $81 \%-100 \%$ & Sangat Setuju \\
\hline
\end{tabular}

Gambar 20 Kriteria Interpretasi Skor

\section{Grafik Hasil Kuisioner}

a. Grafik Kuisioner Sebelum Menggunakan Aplikasi

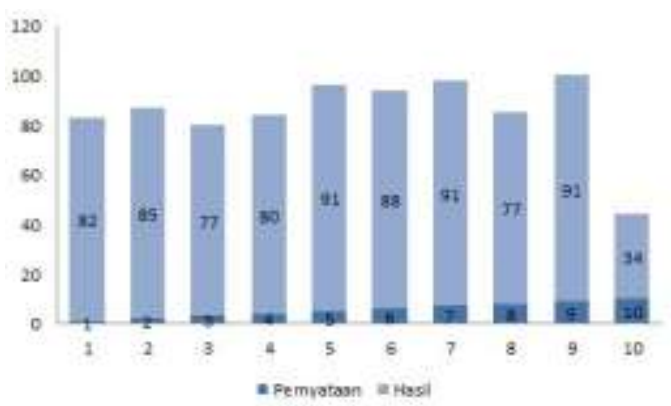

Gambar 21 Grafik Kuisioner Sebelum Menggunakan Aplikasi b. Grafik Kuisioner Sesudah Menggunakan Aplikasi

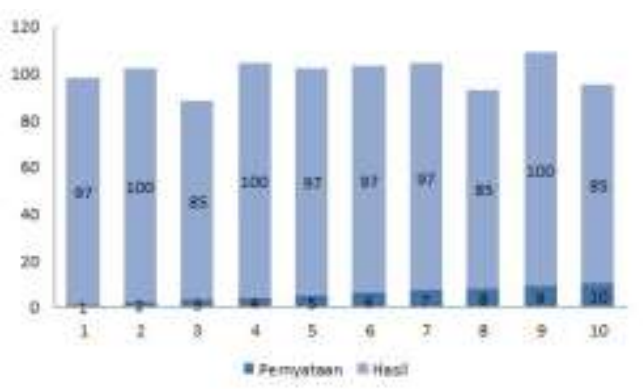

Gambar 22 Grafik Kuisioner Sesudah Menggunakan Aplikasi

9. Kesimpulan Kuisioner

9.1 Kesimpulan Kuisioner Sebelum Menggunakan Aplikasi

a. Sangat Setuju kesulitan dalam mengelola data obat atau barang secara manual.

b. Sangat Setuju kesulitan untuk mengetahui stok obat atau barang secara manual.

c. Setuju kesulitan membuat list obat atau barang untuk diajukan ke supplier.

d. Setuju kesulitan dalam membuat nota/struk pembayaran.

e. Sangat Setuju kesulitan dalam menambah dan mengurangi stok obat atau barang.

f. Sangat Setuju membutuhkan waktu lama dalam pendataan obat atau barang secara manual.

g. Sangat Seuju kesulitan dalam membuat laporan transaksi secara maual.

h. Laporan transaksi dapat dimanipulasi.

i. Sangat Setuju membutuhkan waktu lama dalam membuat laporan transaksi secara manual.

j. Kurang Setuju sistem penjualan tanpa aplikasi masih layak digunakan.

9.2 Kesimpulan Kuisioner Sesudah Menggunakan Aplikasi

a. Sangat Setuju aplikasi ini mempermudah dalam mengelola data obat atau barang menggunakan aplikasi

b. Sangat Setuju aplikasi ini mempermudah dalam mengetahui stok

c. Sangat Setuju aplikasi ini mempermudah membuat list obat atau barang untuk diajukan

d. Sangat Setuju aplikasi ini mempermudah dalam membuat nota/struk pembayaran

e. Sangat Setuju aplikasi ini mempermudah dalam menambah dan mengurangi stok obat atau barang

f. Sangat Setuju aplikasi ini mempercepat pendataan obat atau barang

g. Sangat Setuju aplikasi ini mempermudah dalam pembuatan laporan transaksi

h. Sangat Setuju laporan transaksi tidak dapat dimanipulasi dalam aplikasi

i. Sangat Setuju aplikasi ini mempercepat dalam pembuatan laporan transaksi

j. Sangat Setuju aplikasi penjualan ini layak digunakan 


\section{Simpulan dan Saran}

Dari hasil penelitian, perancangan dan implementasi yang telah dilakukan maka dapat disimpulkan beberapa hal sebagai berikut:

a. Sistem ini dapat mempermudah gudang dalam mengelola obat atau barang di Apotek Sahabat.

b. Sistem ini dapat mempercepat kasir dalam proses transaksi penjualan di Apotek Sahabat.

c. Dengan adanya sistem ini dapat mengupdate stok barang gudang secara Real-time

d. Sistem ini dapat membuat laporan penjualan yang ada di Apotek Sahabat.

Apotek sahabat dapat menggunakan sistem ini dengan sebaik - baiknya. Agar sistem dapat mengelola dan memproses data dengan lebih efektif dan efesien.

\section{Daftar Pustaka}

[1]. Ali, M. (1992). Penelitian Pendidikan Prosedur dan Strategi. Bandung: Angkasa.

[2]. Fahrisa, Sentosa Pohan, \& Marnis Nasution. (2018). PERANCANGAN SISTEM INVENTORY BARANG PADA. Informatika : Jurnal Ilmiah AMIK Labuhan Batu, 18.

[3]. Hall, S. (2010). How to Use the Likert Scale in Statistical Analysis.

[4]. Jogiyanto, H. (2005). Analisis \& Desain Sistem Informasi Pendekatan Terstruktur Teori dan Praktek Aplikasi Bisnis. Yogyakarta: Andi.

[5]. Martin, F. (2005). UML Distiled : A Brief Guide to The Standar Object Modeling Language. Addison Wesley.

[6]. Moekijat. (2011). Latihan dan Pengembangan Sumber Daya Manusia, Bandar. Bandung: Banjar Maju.

[7]. Rangkuti, F. (2004). Manajemen Persediaan Aplikasi di Bidang Bisnis. Jakarta: PT. Raja Grafindo Persada.

[8]. Sukmadinata. (2004). Kurikulum dan Pembelajaran Kompetensi. Bandung: Kesuma Karya.

[9]. Wahana. (2006). Apa \& Bagaimana E-Commerce. Yogyakarta: Andi.

[10]. Wulandari, \& Siska Aprilia. (2015). SISTEM INFORMASI PENJUALAN PRODUK BERBASIS WEB PADA CHANEL DISTRO PRINGSEWU. Jurnal TAM (Technology Acceptance Model) Volume 4, 43. 